\title{
MILLENNIAL SURFACE WATER DYNAMICS IN THE RÍA DE VIGO DURING THE LAST 3000 YEARS AS REVEALED BY COCCOLITHS AND MOLECULAR BIOMARKERS
}

\author{
Álvarez, M. C. ${ }^{1,}{ }^{*}$, Flores, J.A. ${ }^{1}$, Sierro, F.J. ${ }^{1}$, Diz, P. ${ }^{2}$, Francés, G. $^{2}$, Pelejero, \\ C. ${ }^{3,4}$, Grimalt, J. $^{3}$ \\ $\left(^{1}\right)$ Departamento de Geología, Facultad de Ciencias, Universidad de \\ Salamanca, 37008 Salamanca, Spain. \\ ( ${ }^{2}$ ) Departamento de Geociencias Mariñas e Ordenación do Territorio, Facultad \\ de Ciencias, Universidad de Vigo, 36200 Vigo, Spain. \\ $\left({ }^{3}\right)$ Departamento de Química Ambiental (ICER-CSIC), Jordi Girona 18, 08034 \\ Barcelona, Spain. \\ $\left({ }^{4}\right)$ Research School of Earth Sciences, The Australian National University, \\ 0200 ACT, Australia
}

\begin{abstract}
A combined study of coccolithophore assemblages and biomarkers in a gravity core situated in the Ría de Vigo (NW Spain) allowed us to reconstruct the paleoenvironmental conditions for the last 3000 years. The quantitative distribution of coccolithophore species points to three different intervals within the core, dated by AMS radiocarbon measurements. The first interval (ca. 975 BC-252 AD), characterized by high abundances of Calcidiscus leptoporus and Gephyrocapsa muellerae, is thought to represent moderate water temperatures, suggesting a transition from a warmer to a cooler period. The second interval (ca. 252-1368 AD), characterized by the dominance of Coccolithus pelagicus, Helicosphaera carteri and Syracosphaera spp., and a high concentration of hexacosanol linked to terrestrial input, is interpreted as having been a humid period with fluvial input. The third interval (ca. 1368 AD-1950) is characterized by a high abundance of Gephyrocapsa oceanica, high values of alkenones and
\end{abstract}


low values of hexacosanol, and is thought to represent a period dominated by oceanic conditions within the Ría.

Taking into account the ocean-atmospheric system affecting in the region studied, here we propose an alternation in the mean state of North Atlantic Oscillation (NAO) on millennial time scales. A well developed upwelling system and an active Ría-ocean connection during the warmer interval I, suggest a NAO+ phase influenced by a Hypsithermal period. The occurrence of the humid and relatively warm Interval $\mathrm{II}$ is consistent with a negative phase in the NAO, as well as a relative restriction in ocean-Ría exchange. Interval III, which was drier and more productive, suggests again a dominance of a positive phase in the NAO, with a more intense oceanic connection and more energized upwelling.

Keywords: North Atlantic, Ría de Vigo, Coccoliths, Molecular Biomarkers, Alkenones, Holocene, Hypsithermal, North Atlantic Oscillation (NAO).

\section{Introduction and oceanographic setting}

A ría is a river valley that has been invaded by the sea (Derruau, 1983). The Ría de Vigo is located on the Spanish Atlantic coast and is the most southern one of the group known as the "Rías Bajas" (Fig. 1). It is oriented along a central axis, direction $\mathrm{N} 45^{\circ} \mathrm{E}$, and occupies an area of $176 \mathrm{~km}^{2}$. Along the major axis (33 km), is a central channel, with a maximum depth of $45 \mathrm{~m}$ at the mouth. The San Simón Inlet is the narrowest, most inland portion of the Ría (Fig. 1). 
This Inlet is connected through the narrow $(600 \mathrm{~m})$ Rande Strait to the Ría. The Cies Islands, to the west, form a natural barrier to the sea, resulting in relatively calm conditions in the Ría de Vigo (Vilas et al., 1995; Fig. 1).

The Ría de Vigo overlies a bedrock that was heavily fractured during the Hercynian orogeny (IGME, 1981). These tectonic dynamics, together with subsidence and the Flandrian transgression (Derruau, 1983) resulted in the Fiord-like morphology of the Rías. These characteristics are now seen in a complex system in which ocean and continent interact, leaving a mixed signature of both environments in the sediments of the Ría.

The Ría de Vigo area is affected by the East North Atlantic Water (ENAW) circulation pattern. This anticyclonic circulation produces an upwelling system at the mouth of the Ría, resulting in lower surface water temperatures, higher nutrient contents, and high primary production (García-Gil et al., 1995; Prego, 1993). Water dynamics inside the Ría de Vigo, follow an estuarine circulation pattern, with a deep current flow into the Ría, and surface water export out of the Ría (García-Gil et al., 1995). Overprinting this general pattern, a seasonal wind system affects this estuarine circulation. During summer, an anticyclonic wind circulation linked to the Azores High belt reinforces the estuarine pattern (Álvarez-Salgado et al., 1993), with an enhancement of upwelling due to stronger northern winds. Conversely, during winter, the southern position of the Atlantic Low belt, defines a dominant southerly wind regime. At this time, the interchange between the Ría and the ocean is diminished or is interrupted. 
The dominant upwelling phases produce a mixture in the water column; conversely, when upwelling is weakened, circulation between the Ría and the open ocean decreases, and the waters become stratified (García-Gil et al., 1995). Modern river discharge has also introduced anthropogenically-produced nutrients from fertilizers that can produce peaks of higher productivity, although always in minor proportions as compared to the above process. Today, the sewer outlet of the City of Vigo accounts for most of the organic carbon delivered into the Ría de Vigo (Prego, 1993).

The Ría de Vigo is a high-productivity area where diatoms, dinoflagellates, coccolithophores and other microorganisms are abundant. Here we focus on coccolithophores, planktonic organisms surrounded by calcium carbonate scales. Their preservation in the sediment provides an excellent record for

characterizing surface water-masses. Assemblages of this group respond to changes in environmental conditions and, together with biogeochemical analyses, provide a tool to reconstruct paleoenvironmental conditions. In the present study we combine the characterization of coccoliths and molecular biomarkers from a sediment core aiming at elucidating changes in the surface water dynamics of the Ría de Vigo for the last 3000 years, monitoring seacontinent interactions in this particular transitional area.

\section{Materials and methods}

Core VIR-18 was collected in 1990 using a "vibrocorer". This core (380 cm long) was retrieved from the central part of the Ría de Vigo $\left(42^{\circ} 14.07 \mathrm{~N}, 8^{\circ} 47.37 \mathrm{~W}\right)$ at a water depth of $45 \mathrm{~m}$ (Fig 1). Dark olive-grey clay and silt with bioclastic 
fragments of mollusks (mainly bivalves and gastropods) are the main constituents of these sediments. Short intervals of bioturbation are the only sedimentary structures observed. Samples for micropaleontological and biochemical analyses were taken systematically every $5 \mathrm{~cm}$, providing a temporal resolution of about $\sim 30$ years in average.

\subsection{Age model}

In this study we used the age model determined by Diz et al. (2002). The chronology is based on two Accelerator Mass Spectrometry (AMS) radiocarbon measurements: one at the 226-228 cm interval (ca. 907-890 AD) on bivalve shells (Venus sp.) found in the same position as when they were alive, and the other at the core bottom, $380 \mathrm{~cm}$, where bioclastic fragments are present. These analyses were carried out at the Paleobotany and Paleolimnology Laboratory of the University of Utrecht. Radiocarbon data were converted into calibrated ages using the Calib 4.3 radiocarbon calibration program (Stuiver et al., 2000, based on Stuiver and Reimer, 1993) (Table I). Ages between these data points are obtained by linear interpolation. Small changes in sedimentation rate are no detected and can be the responsible of some fluctuations in the coccolith abundance record.

\subsection{Smear slide preparations}

Smear slides were prepared using sediment solution decantation. The solution was distributed uniformly in Petri dishes by pumping it in and out several times with a micropipette (in order to create a little water circulation into the dish). A coverslip was placed at the bottom of each dish and decantation was 
performed. The fluid was then withdrawn from each dish. After the dishes had been dried, smear slides were assembled with Canada balsam (Flores and Sierro, 1997).

For quantitative analysis, we used a light polarizing microscope (1250x). Around 500 coccoliths were counted per slide. To provide percentages and absolute abundances as Flores and Sierro (1997) referred. Additional Scanning Electron Microscope analyses were carried out in selected samples to precise about taxonomical aspects and to observe preservation features.

\subsection{Coccolith preservation}

Coccolith preservation in the analysed samples can be considered good to moderate (see for example Roth and Thierstein, 1972; Flores and Marino, 2002). Punctual observations in the ring elements of small placoliths and other fragile liths allow us conclude that only small etching affected the assemblage along the VIR-18 core. In all the cases this dissolution sings does not preclude the taxonomical identification.

\subsection{Molecular biomarkers}

Variations in selected molecular biomarker abundances through the sedimentary record have often been used to assess the relative importance of the different organic matter sources over time. Amongst the most studied compounds are the $\mathrm{C}_{37}$ alkenones, which allow the establishment of paleo-sea surface temperatures (SST) by means of the $\mathrm{U}^{\mathrm{K}}{ }_{37}$ index (initially defined by

Brassell et al., 1986 and later simplified as $U^{K^{\prime}}$ by Prahl et al., 1988). These 
Haptophyte algae-derived compounds are also interpreted frequently in terms of paleo-marine primary production (e.g. Villanueva et al., 1997a, Budziak et al., 2000). Other biomarkers of relevance are the higher plant derived long chain alkanes and alcohols (Eglinton and Hamilton, 1967), which help elucidate changes in continental supply to the sediments (e.g. Ikehara et al., 2000; Calvo et al., 2001).

In this study, we present previously published data (Diz et al., 2002) on alkenone and $n$-hexacosan-1-ol concentrations as well as SSTs derived from the $\mathrm{U}_{37}^{\mathrm{K}}$ index, that were generated using published methods (Villanueva et al., 1997b). Translation of $U^{K^{\prime}}{ }_{37}$ ratios into SST was achieved using the global coretop calibration equation of Müller et al., $\left(1998 ; \mathrm{U}^{\mathrm{K}^{\prime}}{ }_{37}=0.033 \mathrm{SST}+0.044\right)$.

\section{Results}

\subsection{Coccolithophore assemblage}

The coccolithophore assemblage of core VIR-18 is mainly represented for eight taxa: Calcidiscus leptoporus (Murray and Blackman, 1898) Loeblich and Tappan, 1978 f. leptoporus, Gephyrocapsa muellerae Bréhéret, 1978, Coccolithus pelagicus (Wallich, 1877) Schiller, 1930 f. pelagicus, Helicosphaera carteri (Wallich 1877) Kamptner, 1954 var. carteri, Syracosphaera spp. Lohmann, 1902, Gephyrocapsa oceanica Kamptner, 1943, Emiliania huxleyi (Lohmann, 1902) Hay and Mohler, in Hay et. al., 1967 var. huxleyi and the group "small" Gephyrocapsa (this group includes species with a maximum

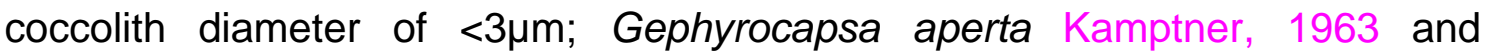
Gephyrocapsa ericsonii Mclntyre and Bé, 1967). The "small" Gephyrocapsa 
group (more than $50 \%$ of the total abundance) and E. huxleyi (27\%) are the dominant taxa. G. oceanica reaches $7 \%$ whereas the other species fluctuate between 1 and 2\% (Fig. 2). The downcore accumulation rate of each taxon is shown in Figure 3. C. leptoporus and G. muellerae have similar profiles and the maximum accumulation rate of both taxa appears between 380 and $280 \mathrm{~cm}$ (ca. $975 \mathrm{BC}-252 \mathrm{AD}$ ). From $280 \mathrm{~cm}$ to the top of the core the accumulation rate of both species diminishes. The trend of E. huxleyi is similar to those of the two above-mentioned species, although its accumulation rate is higher. The "small" Gephyrocapsa group shows two peaks of maxima, one in the lower part of the core and the other close to the core top; the lowest accumulation rate occurred in the central part. The accumulation rates of $C$. pelagicus, $H$. carteri and Syracosphaera spp. are low in the lower and upper parts of the core, while the maximum accumulation rates of these species occurred within the interval between 280 to $125 \mathrm{~cm}$ (ca. 252-1368 AD). Interestingly, each of these species maximize at different times within this period, in the following sequence: first, $\mathrm{C}$. pelagicus peaks at $\sim 1000 \mathrm{yr} A D$, followed by maxima of $H$. Carteri at $\sim 1100 \mathrm{yr}$ AD and Syracosphaera spp. at $\sim 1300$ yr AD with $G$. oceanica having a low accumulation rate throughout the core except for an abrupt increase starting from $125 \mathrm{~cm}$ (ca. 1368 AD).

With the only objective of simplify our results and to compare with other proxy techniques, the core is divided in three intervals taking into account the total abundance of coccolithophores, as well as the record of selected species (Fig. 4). Interval I is defined from the core bottom to $280 \mathrm{~cm}$ (ca. 975 BC-252 AD), and is characterized by a high abundance of C. leptoporus and G. muellerae. 
Interval II, from 280 to $125 \mathrm{~cm}$ (ca. 252-1368 AD), correspond with the lowest values in total abundance of coccoliths and highest values in the proportion of C. pelagicus, H. carteri and Syracosphaera. Finally, Interval III, from $125 \mathrm{~cm}$ to the core top (ca. 1368 AD-1950) is defined by moderate values in the total abundance of coccoliths and the dominance of G. oceanica in the upper part; this variation inside Interval III allow us to separate two different subintervals, IIIa and IIIb, respectively (Fig. 3).

\section{Ecological meaning of coccolithophore assemblages}

The coccolithophores are authothrophic organisms living in the euphotic layer. Assemblage structure is controlled by different factors such as water light intensity, water temperature, nutrients content, salinity... (Brand1994; Young, 1994). We summarized in this section the ecological characteristic of the most significant species identified in this study according with data provided by different specialist.

E. huxleyi is a cosmopolitan and highly eurytopic species (Roth, 1994). When E. huxleyi appear together with "small" Gephyrocapsa (Gephyrocapsa ericsonii and Gephyrocapsa aperta) being part of the coccoliths assemblage , is considered as upwelling proxy (Wells and Okada, 1997).

C. leptoporus is a tropical species living habitually between 20 and $30^{\circ} \mathrm{C}$ in oligotrophic conditions (Giraudeau and Rogers, 1994), whereas G. muellerae is a cold Atlantic species (Knappertsbusch et. al., 1997; Flores et al., 1997) equivalent to the "Gephyrocapsa Cold" morphotype of Bollman (1997). Also, G. 
muellerae is related to subarctic cold waters with mean temperatures lower than $20^{\circ} \mathrm{C}$ and with moderately productive surface waters (Bollman, 1997).

C. pelagicus is a cold water species (Mclntyre and Bé, 1967; Okada and Mclntyre, 1979), but other factors such as a constant input of nutrients in a moderate regime of turbulence can control the presence or abundance of this species (Cachão, 1995; Cachão and Moita, 2000). H. carteri preferentially occurs in tropical and subtropical waters (Okada and Mclntyre, 1979) but can also be found in high-productivity waters (Pujos, 1992; Flores et al., 1995), whereas Syracosphaera spp. prefers warm and stratified waters (Jordan et al., 1996). Colmenero-Hidalgo et. al. (2004) (in press) observed in the Gulf of Cadiz that increases of $H$. carteri and Syracosphera spp. are related with input of turbid and fresher waters.

G. oceanica is recorded in upwelling areas, or is at least relatively abundant in stratified waters (Winter, 1982) and equivalent to the "Gephyrocapsa Equatorial" morphotype of Bollmann (1997) strongly correlated with water temperatures above $25^{\circ} \mathrm{C}$.

\section{Discussion}

\subsection{Interval I: $380-280 \mathrm{~cm}(\mathrm{ca} .975 \mathrm{BC}-252 \mathrm{AD})$}

This interval is characterized by the highest abundance of coccoliths. The dominant species there are E. huxleyi and "small" Gephyrocapsa, but also C. leptoporus and G. muellerae present high values (Figs. 2, 3 and 4). Taking into account the environmental preferences of the above mentioned species, we can 
interpret an oceanic influence with a mixture of relatively warm and cold-water markers.

For this period, calculations obtained using biomarkers give higher temperature values $\left(16.5^{\circ} \mathrm{C}\right.$ at $\left.325 \mathrm{BC}\right)$ (Fig. 4) the highest recorded along the core, although it is important to point out that temperature ranges is around $3^{\circ} \mathrm{C}$, coinciding with data previously showed by Desprat et al. (2003) and Bond et. al. (1997).

For the same core, Diz et. al. (2002) did not detect significant changes in the data from foraminifera and they described only one interval from the core base to 1000 years AD but Desprat (2001) and Desprat et al (2003) distinguished two periods, based on pollen fluxes, between ca. 950 years $B C$ and 450 years AD with a relatively cool period from 1000 to 250 years $B C$, and a warm period between $250 \mathrm{BC}$ and $450 \mathrm{AD}$ (Table. II). The first cold period recorded in the VIR-18 core can be correlated with a cold and humid period recorded in North Europe and corresponds to the Subboreal-Subatlantic transition (ca. 850 BC450 AD) (van Geel et al., 1996).

Interval I, seems to be a transition period between the end of a warmer period and the beginning of a colder one. The warmer period could be the "Hypsithermal" period, dated between 8000 and 2000 BP (corresponding to 6050-50 BC) (Levac, 2001; Boudreau et al., 2001). The bottom of core VIR-18 (975 years BC), with higher SSTs than present and high total abundance of coccoliths, may correspond to the last part of the "Hypsithermal" period. The 
interpretation of this interval as a transition period has also been proposed by Martinez-Cortizas et al. (1999) (Table. II), who calculated the temperature index in Galicia using the accumulation of atmospheric mercury in a peat. Strong temperature fluctuations are the most significant characteristic feature in the interval between 1000 to 250 years BC. Moreover, strong sea level oscillations and changes in the prevailing winds have been reported during 1050-800 BC in northern Spain (Goy et al., 1996). The relatively low values recorded in that abundances of $C$. pelagicus are in agreement with the relatively high temperature; however, inversely, the high values of G. muellerare are interpreted here as oceanic influence.

\subsection{Interval II: $280-125 \mathrm{~cm}$ (ca. $252-1368$ AD)}

During this interval are recorded the lower values in the accumulation rate of total coccoliths, together a net increase in C. pelagicus, $H$. carteri and Syracosphaera spp. (Fig. 3).

The SST estimeted for this interval reached mean values of $15.5^{\circ} \mathrm{C}$. Alkenones display intermediate abundances between $\sim 1500 \mathrm{ng} / \mathrm{g}$ at 1000 AD, and increases afterwards reaching values of $\sim 2500 \mathrm{ng} / \mathrm{g}$. During this period, the terrestrial marker hexacosanol presents a pattern inverse to that of $\mathrm{C}_{37}$ alkenones, with maximum values $(\sim 7000 \mathrm{ng} / \mathrm{g})$ in the earlier part of the interval (252-1059 AD) and a decreasing trend afterwards. There is an interesting correlation between the abundance of $C$. pelagicus and hexacosanol (Fig. 5) that holds for most of the core. The quasi-parallel record observed between hexacosanol and $C$. pelagicus is not well understood; an suggested 
explanation, thinking in the observed relationship between this taxon and nutrient content (Cachão, 1995; Cachão and Moita, 2000) is the increase in the fluvial nutrient supply in the Ría that can enhance the production of $C$. pelagicus. Although a decrease in the SST can produce a similar effect.

Similarly, total abundance of coccoliths depicts an inverse correlation to hexacosanol, particularly during this interval but also throughout most of the core. This fact can be explained as dilution process due to land input to the sedimentary context.

The observed peaks of $H$. carteri and Syracosphaera spp. are interpreted here as episodes of increase in surface water stratification. Colmenero-Hidalgo et. al. (2004, in press) observed the same response of these taxa in the Mediterranean sea. In the Ria de Vigo, fluvial input can produce stratification by changing the mixing regime (Diz et al., 2002). However, we can not discard a relationship with factor no well understood: this time is coincident with the Medieval Warm Period (Table 2), that as is shown in Figure 4, is not recorded in the surface water temperature.

Two pollen zones have been defined by Desprat (2001) and Desprat et al. (2003) in this interval: from 450 to 950 AD and from 950 to 1400 AD. The first interval is considered cold and humid, whereas the second is interpreted as warmer. The cold and humid period coincides with a peak in the hexacosanol record. 
In summary, interval II indicates a stronger continental influence, with a decrease in SST. A weak upwelling, with episodes of stratification from increased river input in the Ría, stopped the estuarine circulation. This explanation is in agreement with the wind pattern provided by Goy et al. (1996) for this period, which indicated prevailing winds blowing from west-southwest and drastic reductions in estuarine connections with the open sea.

\subsection{Interval III: $125 \mathrm{~cm}$-core top (ca. 1368-1950 AD)}

This interval characterized for high abundances of "small" Gephyrocapsa, with a clear peak of G. oceanica at 1690 AD. (Fig. 6) corresponds with a return of oceanic influence, especially enhanced in the top of the core (between 1691 and $1950 \mathrm{AD})$.

For this interval, the paleotemperature record shows the lowest values along the core, $13.3^{\circ} \mathrm{C}$ at $1424 \mathrm{AD}$ (Fig. 4). The profile of hexacosanol shows lower values in this interval, whereas the alkenones have also high concentrations in the core top.

Desprat (2001) and Desprat et al. (2003), studding pollen defined subintervals from 1400-1860 AD and 1860-1983 AD, corresponding with a relatively warm and cold periods, respectively. These pollen intervals coincided with those defined for us with coccolithophores and are in agreement with the historical data provided by Font Tullot (1998), who reported a cold period at around 1760 AD. 
The coccolithophore assemblage observed in this interval suggests a reinforcement in the connection between the Ría and the ocean, in agreement with previous interpretations based on benthic foraminifera and molecular biomarkers (Diz et al., 2002).

A change in the wind direction from the north to the southwest, as suggested Goy et al. (1996) and Diz (1998), and a consequent intensification in the upwelling, caused a decrease in the surface-water temperature and an increase in nutrient fluxes to surface waters.

In Table II we summarized our results as well as the correlation with intervals/episodes defined by other proxies. It is interesting to point out that, whereas the continental record (especially the pollen, but also the mercury in peat bogs) is easy to correlate with the climatic episodes described during the late Holocene in Europe, the Ria the organisms react in different way, not always in a direct correspondence with the global temperature.

\subsection{Possible inferences on the mean state of the North Atlantic Oscillation}

The North Atlantic Oscillation (NAO) is an alternation of air masses that occurs between subtropical regions (centered over the Azores Islands and Portugal), and the sub-polar regions of the North Atlantic (centered over Iceland) (Fromentin and Planque, 1996). During periods of positive NAO, when a well developed high atmospheric pressure close to Azores Islands and a low pressure close to Iceland exist, strong westerly winds develop across the midlatitude North Atlantic region. In Europe, this situation results in a general warming, with enhanced precipitation in the North and dryness in the South 
(Fig. 7a). Conversely, during periods of negative NAO, when the high atmospheric system over Azores Islands is weakened, westerlies across the North Atlantic region are weakened, resulting in cold temperatures in northern Europe but increased rainfall over southern Europe (Fig. 7b).

The NAO exhibits prolonged periods of both positive and negative phases. During the last century, for instance, the positive phase of the NAO dominated the atmospheric circulation from the 1900s until about 1930 (Hurrell 1995). From the early 1940 s until the early 1970 s, the negative phase was dominant, and later another positive phase was recorded up to the 1990s (Hurrell 1995). But the use of other long-term proxies such as ice cores, dendrochronology, snow accumulation, etc. allowed reconstruct decadal and even secular variations of NAO (Glueck and Stockton (2001); Cullen et. al. (2001)).

Interpretation of NAO-related processes in the past have been reported (Giraudeau et al., 2000; Sánchez-Goñi et al., 2002), in the surroundings of our area of study (Dresprat et al., 2003) but also in the North Atlantic (Chapman and Shackleton, 2000, Bianchi and McCave, 1999, Bond et al., 1997) revealed the Holocene characterized by a millennial scale climatic variability.

As hypothesis, we propose that the surface water variations observed in the Ría de Vigo can be controlled for changes in atmospheric cells gradient than modify the NAO at millennial scale. As results of that, we interpret that our results respond to changes in intensity and wind direction, as well as in precipitations. As we explain, the interval I, a transitional period, is characterized by relatively 
high temperatures and oceanic influence. The higher temperatures are related with a progressively weaker Hypsithermal period and the Azores High position controls the atmospheric circulation in this zone (Fraga, 1991). Therefore, oceanic influence, related to a well developed Azores High, provoking a positive NAO (+) situation.

During Interval II surface-water stratification is the dominant scenario in the Ria de Vigo, related with increase of runoff (Desprat, 2001), and changes in the wind regime. The available data suggest a negative phase of the NAO (-).

During interval III, more oceanic influence conditions were dominant in the region, with weak freshwater input into the Ría and a well developed upwelling. These data are consistent with a lower humidity on the continent linked to a dominant positive phase of the NAO $(+)$, with different characteristics that those observed in interval I.

\section{Conclusions}

Coccolith abundances, and molecular biomarker record obtained from core VIR18 from the Ría de Vigo evidence changes in the hydrographic and atmospheric regimes and interactions between the Ría and the open ocean over the last 3000 years.

Our data allowed identify events with different environmental conditions which were interpreted here as follows:

Interval I (ca. 975 years BC-252 AD), is characterized by a maximum accumulation rate of $C$. leptoporus and $G$. muellerae, suggesting a transition 
from a warmer to a colder period. This transitional warm interval with oceanic influence might be indicative of a prevalence of a positive phase of NAO.

Interval II (ca. 252-1368 AD) is characterized by asynchronous peaks in the accumulation of C. pelagicus, H. carteri and Syracosphaera species. This interval is associated with high continental runoff and surface-water stratification, as indicated by high hexacosanol concentrations. This humid interval could be associated with a prevailing negative phase in the NAO, which is commonly associated with enhanced precipitation in southern Europe. Interval III (ca. 1368-1950 AD) is characterized by a significant and progressive increase in the distribution of $G$. oceanica, together with higher $\mathrm{C}_{37}$ alkenone values. This interval shows an enhanced marine influence to the Ría, concomitant with a reduction in fluvial input evidenced by a clear decrease in hexacosanol concentrations. This situation is in agreement with a prevailing positive phase of the NAO.

\section{Acknowledgements}

The authors wish to express their thanks to Ric Jordan and other anonymous reviewer for their valuable and critical comments. Research grants ABRUMIS REN2003-08642-C02-02/CLI, BTE2002-04670 (Ministerio de Ciencia y Tecnología) and SA088/04 (Junta de Castilla y León) supported this study. 


\section{References}

Álvarez, M.C., Flores, J.A., Sierro, F.J., Fuertes, M.A., Pelejero, C., G Francés, G., 2000. Evolución de los cocolitofóridos durante los últimos 3000 años en la ría de Vigo. I Congresso Ibérico de Paleontología. XVI Jornadas de la Sociedad Española de Paleontología, Livro de Resumos, Diez, J.B. e Balbino, A.C. (eds), Évora, Portugal, 31-32.

Álvarez-Salgado, X.A., Rosón, G., Pérez, F.F., Pazos, Y., 1993. Hydrographic variability off the Rías Baixas (NW Spain) during the upwelling season. Journal of Geophysical Research 98, 14,447-14,455.

Bianchi, G.G. McCave, I.N., 1999. Holocene periodicity in North Atlantic climate and deep-ocean flow south of Iceland. Nature 397, 515-517.

Bollmann, J., 1997. Morphology and biogeography of Gephyrocapsa coccoliths in Holocene sediments. Marine Micropaleontology 29, 319-350.

Bond, G., Showers, W., Cheseby, M., Lotti, R., Almasi, P., deMenocal, P., Priore, P., Cullen, H., Hajdas, I., Bonani, G., 1997. A pervasive millennial-scale cycle in North Atlantic Holocene and glacial climates. Science 278, 1257-1266.

Boudreau, R.E.A, Patterson, R.T., Dalby, A.P., McKillop, W.B., 2001. Nonmarine occurrence of the foraminifer Cribroelphidium gunteri in northern Lake Winnipegosis, Manitoba, Canada. Journal of Foraminiferal Research 31(2), 108-119.

Brassell S. C., Eglinton G., Marlowe I. T., Pflaumann U., and Sarnthein M. 1986. Molecular stratigraphy: a new tool for climatic assessment. Nature $320,129-133$. 
Budziak D., Schneider R. R., Rostek F., Müller P. J., Bard E., and Wefer G. 2000. Late Quaternary insolation forcing on total organic carbon and C37 alkenone variations in the Arabian Sea. Paleoceanography 15 (3), 307321.

Cachão, M., Moita, M.T., 2000. Coccolithus pelagicus, a productivity proxy related to moderate fronts off Western Iberia. Marine Micropaleontology 39, 131-155.

Cachão, M., 1995. Utilização de Nanofósseis Calcários em Biostratigrafia, Paleoceanografia e Paleoecologia. Tese de Doutoramento, Faculdade de Ciências da Universidade de Lisboa, Portugal.

Calvo, E., Villanueva, J., Grimalt, J. O., Boelaert, A., Labeyrie, L. 2001. New insights into the glacial latitudinal temperature gradients in the North Atlantic. Results from UK'37 - sea surface temperatures and terrigenous inputs. Earth and Planetary Science Letters 188, 509-519.

Chapman, M.R., Shackleton, N.J., 2000. Evidence of 550-year and 1000-year cyclicities in North Atlantic circulation patterns during the Holocene. The Holocene 10 (3), 287-291.

Colmenero-Hidalgo, E., Flores, J.A., Sierro, F.J., Bárcena, M.A., Löwemark, L., Schönfeld, J., Grimalt, J.O., 2004. Ocean surface water response to short-term climate changes revealed by coccolithophores from the Gulf of Cadiz (NE Atlantic) and Alboran Sea (W Mediterranean). Palaeogeography, Palaeoclimatology, Palaeoecology, (in press).

Cullen, H.M., D'Arrigo, R.D., Cook, E.R., 2001. Multiproxi reconstructions of the North Atlantic Oscillation. Paleoceanography 16 (1), 27-39.

Derruau, M., 1983. Geomorfología. Ariel Geografía. Barcelona. 
Desprat S., Sánchez-Goñi, M.F., Loutre, M.F., 2003. Revealing climatic variability of the last three millennia in northwestern Iberia using pollen influx data. Earth and Planetary Science Letters 213, 63-78.

Desprat S., 2001. Réponse continentale aux changements climatiques des derniers 3000 ans dans les latitudes moyennes de l'Atlantique Nord: Analyse pollinique des sédiments marins de la Ría de Vigo (Nord Ouest de la Péninsule Ibérique). Rapport de DEA, Département de Géologie et d’Océanographie, Université Bordeaux I, France.

Diz, P., Francés, G., Pelejero, C., Grimalt, J.O., Vilas, F., 2002. The last 3000 years in the Ría de Vigo (NW Iberian Margin): climatic and hydrographic signals. The Holocene 12, 459-468.

Diz, P., 1998. Evolución Paleoecológica y Paleoceanográfica de la Ría de Vigo durante el Holoceno. Grado de Licenciatura, Facultad de Ciencias, Universidad de Vigo, Spain.

Eglinton, G., Hamilton. R.J., 1967. Leaf epicuticular waxes. Science 156, 13221335.

Flores, J.A., Marino, M., 2002. Pleistocene calcareous nannofossil stratigraphy for ODP Leg 177 (Atlantic sector of the Southern Ocean). Marine Micropaleontology 45, 191-224.

Flores, J.A., Sierro, F.J., 1997. Revised technique for calculation of calcareous nannofossil accumulation rates. Micropaleontology 43 (3), 321-324.

Flores, J.A., Sierro, F.J., Francés, G., Vázquez, A., Zamarreño, I., 1997. The last 100,000 years in the western Mediterranean: sea surface water and frontal dynamics as revealed by coccolithophores. Marine Micropaleontology 29, 351-366. 
Flores, J.A., Sierro, F.J., Raffi, I., 1995. Evolution of the calcareous nannofossil assemblage as a response to the paleoceanographic changes in the Eastern equatorial Pacific from 4 to 2 Ma (Leg 138, Sites 849 and 852). Proceedings ODP Initial Report 138, 163-176.

Font Tullot, I., 1998. Historia del clima de España. Cambios climáticos y sus causas. Instituto Nacional de Meteorología, Madrid.

Fraga, F., 1991. El afloramiento costero en la costa Atlántica de la Península Ibérica. Revista Académica Galega de Ciencias 10, 144-152.

Fromentin, J.M., Planque, B., 1996. Calanus and environment in the eastern North Atlantic. II. Influence of the North Atlantic Oscillation on C. finmadricus and C. helgolandisas. Marine Ecology Progress Series 134, 111-118.

García-Gil, S., Nombela, M.A., Alejo, I., Pazos, O., Rubio, B., García-Gil, E., Vilas, F., 1995. Dominios y distribución de facies en la Ría de Vigo. Reunión monográfica sobre El cambio de la Costa: Los sistemas de Rías. Universidad de Vigo, Vigo.

Giraudeau, J., Cremer, M., Manthé, S., Labeyrie, L., Bond, G., 2000. Coccolith evidence for instabilities in surface circulation south of Iceland during Holocene times. Earth and Planetary Science Letters 179, 257-268.

Giraudeau, J., Rogers, J., 1994. Phytoplankton biomass and sea-surface temperature estimates from sea-bed distribution of nannofossils and planktonic foraminifera in the Benguela upwelling system. Micropaleontology 40 (3), 275-285. 
Glueck, M.F., Stockton, C.W., 2001. Reconstruction of the North Atlantic Oscillation, 1429-1983. International Journal of Climatology 21, 14531465.

Goy, J.L., Zazo, C., Dabrio, C.J., Lario, J., Borja, F., Sierro, F.J., Flores, J.A., 1996. Global and regional factors controlling changes of coastlines in Southern Iberia (Spain) during the Holocene. Quaternary Science Reviews 15, 773-780.

Hurrell, J.W., 1995. Decadal trends in North Atlantic Oscillation regional temperatures and precipitations. Science 269, 676-679.

IGME, 1981. Mapa Geológico de España, 1:50000. Vigo. Servicio de publicaciones Ministerio de Industria y Energía. Madrid.

Ikehara, M., Kawamura, K., Ohkouchi, N., Murayama, M., Nakamura, T., Taira, A. 2000. Variations of terrestrial input and marine productivity in the Southern Ocean $\left(48^{\circ} S\right)$ during the last two deglaciations. Paleoceanography 15(2), 170-180.

Jordan, R.W., Zhao, M., Eglinton, G., Weaver, P.P.E., 1996. Coccolith and alkenone stratigraphy and palaeoceanography at an upwelling site off NW Africa (ODP 658C) during the last 130,000 years. In: Whatley, R., Moguilevsky, A., (Eds.), Microfossils and Oceanic Environments. Univ. Wales, Aberystwyth Press, Aberystwyth, pp. 111-130.

Knappertsbusch, M., Cortés, M.Y., Thierstein, H.R., 1997. Morphologic variability of the coccolithophorid Calcidiscus leptoporus in the plankton, surface sediments and from the Early Pleistocene. Mar. Micropaleontol. 30, 293-317. 
Levac, E., 2001. High resolution Holocene palynological record from the Scotian Shelf. Marine Micropaleontology 43, 179-197.

Marlowe, I.T., Green, J.C., Neal, A.C., Brassell, S.C., Eglinton, G., Course, P.A., 1984. Long chain ( $\left.n-C_{37}-C_{39}\right)$ alkenones in the Prymnesiophyceae. Distribution of alkenones and others lipids and their taxonomic significance. British Phycological Journal 19, 203-216.

Martinez-Cortizas, A., Valcarcel, M., Pérez-Alberti, A., Castillo, F., Blanco, R., 1999. Mercury in a Spanish peat bog: archive of climate change and atmospheric metal deposition, Science 284, 939-942.

McIntyre, A., Bé, A.W.H., 1967. Modern coccolithophores of the Atlantic, I.

Placoliths and Cyrtoliths. Deep-Sea Research 14, 561-597.

Müller, P. J., Kirst, G., Ruhland, G., von Storch, I., Rosell-Melé, A., 1998. Calibration of the alkenone paleotemperature index $\mathrm{U}^{\mathrm{K}^{\prime}}{ }_{37}$ based on coretops from the eastern South Atlantic and the global ocean $\left(60^{\circ} \mathrm{N}-60^{\circ} \mathrm{S}\right)$. Geochimica et Cosmochimica Acta 62(10), 1757-1772.

Okada, H., Mclntyre, A., 1979. Seasonal distribution of modern Coccolithophores in the western North Atlantic Ocean. Marine Biology $54,319-328$.

Prahl, F.G., Muehlausen, L.A., Zahnle, D.L., 1988. Further evaluation of longchain alkenones as indicators of palaeoceanographic conditions. Geochimica et Cosmochimica Acta 52, 2303-2310.

Prego, R., 1993. General aspects of carbon biogeochemistry in the Ría de Vigo, northwestern Spain. Geochimica et Cosmochimica Acta 57, 2041-2052.

Pujos, A., 1992. Calcareous nannofossils of Plio-Pleistocene sediments from the northwestern margin of tropical Africa. In: Summerhayes, C.P., Prell, 
W.L., Emeis, K. C. (Eds), Upwelling Systems: Evolution Since the Early Miocene. Geological Society Special Publication 64, London, pp.343359.

Roth , P. H., Thierstein, H. 1972: Calcareous nannoplankton: Leg 14 of the Deep Sea Drilling Project. In HAYES, D. E., PIMM, A.C., et al., Initial Reports of the Deep Sea Drilling Project., 14, 421-485.

Roth, P.H., 1994. Distribution of coccoliths in oceanic sediments. In: Winter, A., Siesser, W.G., (Eds.), Coccolithophores. Cambridge University Press, Cambridge, pp.

Sánchez-Goñi, M.F., Cacho, I., Turon, J.L., Guiot, J., Sierro, F.J., Peypouquet, J.P., Grimalt, J.O., Shackleton, N.J., 2002. Synchroneity between marine and terrestrial responses to millennial scale climatic variability during the last glacial period in the Mediterranean region. Climate Dynamics 19, 95105.

Stuiver, M., Reimer, P.J., Reimer, R.W., 2000. CALIB 4.3. [WWW program and documentation] Seattle: University of Washington and Belfast: Queen's University of Belfast. URL:(www.calib.org).

Stuiver, M., Reimer, P.J., 1993. Extended ${ }^{14} \mathrm{C}$ data base and revised Calib 3.0 ${ }^{14} \mathrm{C}$ age calibration program. Radiocarbon $35,215-230$.

Van Geel, B., Buurman, J., Waterbolk, H.T., 1996. Archaeological and palaeoecological indications of an abrupt climate change in the Netherlands, and evidence for climatological teleconnections around 2650 B.P. Journal of Quaternary Sciences 11(6), 451-460 
Vilas, F., Nombela, M.A., García-Gil, E., García-Gil, S., Alejo, I., Rubio, B., Pazos, O., 1995. Cartografía de sedimentos submarinos. Ría de Vigo. Xunta de Galicia, Consellería de Pesca, Marisqueo e Acuicultura. Vigo.

Villanueva, J., Grimalt, J.O., Cortijo, E., Vidal, L., Laberie, L., 1997a. A biomarker approach to the organic matter deposited in the North Atlantic during the Last Climatic Cycle. Geochimica et Cosmochimica Acta 61, 4633-4646.

Villanueva J., Pelejero C., and Grimalt J. O. 1997b. Clean-up procedures for the unbiassed estimation of $\mathrm{C}_{37}-\mathrm{C}_{39}$ alkenone sea surface temperatures and terrigenous $n$-alkane inputs in paleoceanography. Journal of Chromatography 757, 145-151.

Volkman, J.K., Eglinton, G., Corner, E.D.S., Sargent, J.R., 1980. Novel unsaturated straight-chain $\mathrm{C}_{37}-\mathrm{C}_{39}$ methyl and ethyl ketones in marine sediments and a coccolithophore Emiliania huxleyi. In: Douglas, A.G., Maxwell, J.R., (Eds.), Advances in organic geochemistry, Pergamon Press, Oxford, pp. 219-228.

Wells, P., Okada, H., 1997. Response of nannoplankton to major changes in sea-surface temperature and movements of hydrological fronts over Site DSDP 594 (south Chatham Rise, southeastern New Zealand), during the last 130 kyr. Marine Micropaleontology 32, 341-363.

Winter, A., 1982. Paleoenvironmental interpretation of Quaternary coccolith assemblages from the Gulf of Aqaba (Elat), Red Sea. Revista Española de Micropaleontología XIV, 291-314. 


\section{Tables}

\section{Tables captions}

Table. 1. AMS ${ }^{14} \mathrm{C}$ ages (modified after Diz, 2002).

Table 2. Interpretation of different proxies and their relationship with climatic events in the Ria de Vigo

\section{Figure captions}

Fig. 1. Situation of core VIR-18 and general pattern of Eastern North Atlantic Water (ENAW).

Fig. 2. Percentage of selected coccolitophore taxa in core VIR-18.

Fig. 3. Coccolithophore accumulation rate $(\mathrm{N})$ of selected taxa identified in core VIR-18.

Fig. 4. Estimated paleotemperature, molecular biomarker concentration and coccolith total abundance (per visual field, x1250) vs. age (years BC/AD).

Fig. 5. Accumulation rate ( $\mathrm{N}$ ) of Coccolithus pelagicus vs. hexacosanol (ng/g).

Fig. 6. Accumulation rate $(\mathrm{N})$ of Gephyrocapsa oceanica vs. total abundance of coccolithophores per visual field. 
Fig. 7. North Atlantic Oscillation (NAO). General model. a) NAO+: intervals I and III b) NAO-: interval II. In all cases, arrow denotes intensity of the event.

\section{Figures}

